\title{
ACQUISITION OF CORPORATE CONTROL UNDER THE REORGANIZATION AND EXCHANGE PROVISIONS OF THE FEDERAL INCOME TAX
}

GAINS and losses on certain exchanges are not recognized for tax purposes if sustained in the course of a federal income tax reorganization. ${ }^{1}$ Where the problem of corporate control is involved in such reorganizations, the tax statute requires that the degree of control be eighty per cent. 2 At one time, the Commissioner of Internal Revenue and the courts apparently agreed that a reorganization occurred whenever such control existed after an exchange. ${ }^{3}$ But the Commissioner has recently contended that a reorganization occurs only in exchanges where statutory control arises out of the excliange itself.4

1. A federal income tax reorganization is a special type of reorganization defined in the tax statute. It need not be and usually is not the same as an ordinary corporate reorganization under state law or a bankruptcy reorganization under Chapter $\mathrm{X}$ of the Federal Bankruptcy Act. 52 Stat. $\$ 83$ (1938), 11 U. S. C. \$ 501 (Supp. 1939).

See INT. Rev. Code $\$ 112(\mathrm{~g})(1940)$. "As used in this section ... (1) The term 'reorganization' means . . . (B) the acquisition by one corporation, in exchnnge solely for all or a part of its voting stock, of at least 80 per centum of the voting stock and at least 80 per centum of the total number of shares of all other classes of stock of another corporation, or . . . (D) a transfer by a corporation of all or a part of its assets to another corporation if immediately after the transfer the transieror or its shareholders or both are in control of the corporation to which the assets are transferred ..." Since this Comment is addressed to the acquisition of corporate cuntrol under the reorganization and exchange provisions of the Federal Income Tax, only the above parts of the reorganization definition are pertinent. Part (A) refers to mergers or consolidations carried out not under Income Tax Laws but under federal or state corporation laws. U. S. Treas. Reg. 103, $\$ 19.112(\mathrm{~g})-2$. Part (E) is direeted towards rearrangement of a corporation's capital structure, U. S. Treas. Reg. 103, $\$ 19.112$ (g)-2; Part (F) has to do with purely formal changes such as changing a corporate name. Neither (E) nor (F) raises the issue of corporate control. Part (C) is concerned with the acquisition by one corporation of substantially all the properties of another corporation. The crucial question is not control but what constitutes "substantially all the properties ..."

See, generally, Fahey, Income Tax Defintion of "Rcorganization" (1939) 39 CoL L REv. 933.

2. INT. REv. CoDE $§ 112(h)$ (1940) “. . . the term "control" means the ownership of stock possessing at least 80 per centum of the total combined voting power of all classes of stock entitled to vote and at least $S 0$ per centum of the total number of shares of all other classes of stock of the corporation." See also INT. REv: Corz $§ 112(\mathrm{~g})(1)(B)$ (1940), note 1 supra.

The stock control percentages must be computed not on the number of shares authorized but on the number of shares issued by the transferee, Louangel Holding Corp. v. Anderson, 9 F. Supp. 550 (S. D. N. Y. 1934); and it is sufficient if there is equitable rather than legal title to stock, Carel Robinson v. Comm'r, 19 B. T. A. 751, 761 (1934).

3. See notes 29 and 38 infra.

4. Peck \& Peck v. Comm'r, 42 B. T. A. 651, 053 (1940). Although the Commissioner contended only that control be acquired by the transier, the opinion clearly implies 
Though representing an attempt to prevent unwarranted tax avoidance, ${ }^{b}$ this contention seems inadequate in some situations. ${ }^{6}$ It promises to touch off extended legal controversy, not only in connection with reorganizations but also in the allied field of property transfers to a corporation. ${ }^{\text {? }}$

The nonrecognition provisions of the Internal Revenue Code apply to exchanges made in pursuance of a plan of reorganization if the stock being exchanged is that of corporations which are parties to the same reorganization, ${ }^{\mathbf{8}}$ or if one corporation transfers property for stock of another wherc both corporations are parties to the reorganization. ${ }^{0}$ The Code defines "rcorganization"10 and "party to a reorganization," 11 withholding the benefit of the nonrecognition provisions unless these definitions are complied with. It

that $80 \%$ control was meant, not just any accretion which, added to prior stockholdings, results in the statutory figure. The question arose on an interpretation of $\$ 112(\mathrm{~g})(1)$ (C) of the Revenue Act of 1934, now $\$ 112(\mathrm{~g})(1)$ (D) of the Internal Revenue Code (1940), and the Commissioner was unsuccessful in his contention. The issue now lics dormant because the decision has been acquiesced in. 4 Prentice-Hall 1940 Fed. Tax Serv. \66,415. For a summary of the Peck case, see p. 1241 infra.

The Commissioner clearly contended that statutory control must arist oul of the exchange in Comm'r v. Dana, 36 B. T. A. 97, 102, 104 (1937), aff'd, 103 F. (2d) 359 (C. C. A. 3d, 1939), but was again unsuccessful. The issue arose on an interpretation of the stock acquisition part of the old "parenthetical clause" under $\$ 112$ (i) (1) (A) of the Revenue Act of 1928, now $\$ 112(\mathrm{~g})(1)(B)$ of the Internal Revenue Code (1940). The "parenthetical clause" required only majority control by the dominant corporation, but the issue was exactly the same as now exists under the Internal Revenue Code, except that $80 \%$ control is presently necessary.

5. Corporate reorganizations have long been one of the richest fields of tax avoidance. Comment (1935) 45 YALE L. J. 134. There has been considerable agitation to abolish the reorganization and exchange provisions. Seidman, Legislative History or Federal Income Tax Laws (1938) 332 et scq.; Sandberg, The lncomc Tait Sullsidy to "Reorganizations" (1938) 38 CoL. L. REv. 98.

6. See p. 1245 infra.

7. A tax hungry Treasury will be apt to prompt the Commissioner to reassert his position or to raise other similar contentions in an endeavor to restrict tax avoidance, and the history of tax litigation shows that taxpayers can be relicd upon to resist this new phase of governmental encroachment upon their pocketbooks.

8. INT. REv. CODE $\S 112$ (b) (3) (1940). "No gain or loss shall be recognized if stock or securities in a corporation a party to a reorganization are, in pursuance of the plan of reorganization, exchanged solely for stock or securities in such corporation or in another corporation a party to the reorganization."

9. INT. Rev. CODE $\$ 112$ (b) (4) (1940). "No gain or loss shall be recognized if a corporation a party to a reorganization exchanges property, in pursuance of the plan of reorganization, solely for stock or securitics in another corporation a party to the reorganization."

10. See note 1 supra.

11. INT. REr. CODE $\S 112(\mathrm{~g})(2)$ (1940). "The term 'a party to a reorganization' includes a corporation resulting from a reorganization and includes both corporations in the case of a reorganization resulting from the acquisition by one corporation of stock or properties of another." 
also provides that no gain or loss is recognized if one or more persons transfer property to a corporation in exchange for its stock and immediately thereafter control the corporation in proportion to the value of the property which each transfers. ${ }^{12}$ In property transfers to a corporation, as well as in Ieorganizations, the statute demands eighty per cent stock control of the transferee corporation by the transferor(s), ${ }^{13}$ but in neither case does it specify the manner of acquiring that control.

The principal justification of these nonrecognition provisions is that a tax levied on gains at the time of the exchange would seriously interfere with such normal business adjustments as corporate consolidations and mergers, for the gains may be only paper profits. ${ }^{14}$ While a good case can be made for complete elimination of the nonrecognition provisions, legislative policy has clearly been to postpone (not exempt) taxation of transactions yielding large book profits instead of real gains. ${ }^{15}$ The underlying assumption of the nonrecognition provisions, exceptions to the general statutory rule that gain or loss is recognized upon an exchange, ${ }^{10}$ is that the new stock received in place of the stock or property transferred represents a continuation of an old and still unliquidated investment. 17

A "plan" of reorganization is explicitly required in nontaxable exchanges in connection with a reorganization, ${ }^{18}$ and the presence of a "plan" is implied in the related field of property transfers to a corporation. ${ }^{10}$ Statutory corporate control need not be acquired in one transaction; if control exists after the completion of a series of transactions which are part of a clear and

12. INT. REv. CoDE $\$ 112$ (b) (5) (1940). "No gain or loss shall be recognized if property is transferred to a corporation by one or more persons solely in exchange for stock or securities in such corporation, and immediately after the exchange such person or persons are in control of the corporation; but in the case of an exchange by two or more persons this paragraph shall apply only if the amount of the stock and securities received by each is substantially in proportion to his interest in the property prior to the exchange ...."

13. See note 2 sipra.

14. See H. R. Report-Ways and Means Subcommittec, 73d Cong., 2d Sess. (Dec 4, 1933) 37-42; see Sen. Rep. No. 398, 68th Cong., 1st Sess. (1924) 14-15; H. R. Rep. No. 179, 68th Cong., 1st Sess. (1924) 13; Semaran, op. cit. sipra note 5, at 333-334, 690; Comment (1935) 45 Yale L. J. 134.

The reorganization and exchange sections are intended to alleviate the effect of the capital gains tax. Sandberg, loc. cit. stipra note 5.

15. See H. R. Report-IVays and Means Stıbcommittee, 73d Cong., 2d Sess. (Dec 4, 1933) 37; Semdran, op. cit. supra note 5, at 332; Peirce, Incosse Tax Furdarmesitals (1937) 318.

16. INT. REv. CODE $§ 112$ (a) (1940).

17. U. S. Treas. Reg. 103, Sec. 19.112(a)-1.

18. Only exchanges pursuant to a plan of reorganization are tax free. INT. Rev. CODE $\$ 112$ (b) (3 and 4) (1940).

19. See Charles Hall v. Comm'r, 31 B. T. A. 125, 129 (1934); 2 Paul \& Merters, The Law of Federal Income Taxation (1934) $\$ 17.42$. 
authoritative plan, ${ }^{20}$ the statute is satisfied. ${ }^{21}$ But an exchange is tax free only if it is essential to the consummation of a statutory plan. ${ }^{22}$

I.

\section{Reorganization Under Parts (D) and (B) of time Definition}

Part (D) defines a reorganization as "a transfer by a corporation of all or a part of its assets to another corporation if immediately after the transfer the transferor or its shareholders or both are in control of the corporation to which the assets are transferred." 23 Superficially, the words "immediately after" the transfer appear to emphasize the status of the transferor corporation after it has acquired eighty per cent control of the transferee rather than the process by which that control is achieved.24 Insofar as they have expressed themselves, the courts have adopted the apparent status interpretation of the definition without going beyond a literal interpretation of the statute to satisfy the underlying legislative policy.25 Such a juticial attitude opens wide avenues for tax avoidance.

20. A bona-fide reorganization agreement need not be formally approved by corporate directors, Edison Securities Corp. v. Comm'r, 34 B. T. A. 1188 (1936), nor need it be in writing. Munroe v. Comm'r, 39 B. T. A. 685, 700 (1939).

21. Edison Securities Corp. v. Comm'r, 29 B. T. A. 483, 493 (1933), rev'd and rcmanded on other grounds, 78 F. (2d) 85 (C. C. A. 4th, 1935); Munroe v. Comm'r, 39 B. T. A. 685,700 (1939); United Light \& Power Co. v. Comm'r, 105 F. (2d) 866, 874 (C. C. A. 7th, 1939), cert. denied, 308 U. S. 574 (1939); Paul, Studies in Fedeiral. Taxation-Third Series (1940) 74; 402 C. C. H. 1940 Fed. Tax Serv. $\llbracket 728.188$. But preliminary or casual acquisitions of less than the requisite amount of stock may not be lumped together to form an acceptable plan. See Edison Securitics Corp. v. Comm'r, supra. For a general discussion of step reorganizations, see Paud, Selecred Studies in Federal Taxation-Second Series (1938) 200-254.

The statute is not satisfied if control exists' only at the fulfillment of one of the intermediate steps of a plan. Burns v. Comm'r, 30 B. T. A. 163, 172 (1934); Charles Hall v. Comm'r, 31 B. T. A. 125, 129 (1934). But control at the completion of a plan need not be retained for an indefinite period of time. American Compress \& Warehousu Co. v. Bender, 70 F. (2d) 655 (C. C. A. 5th, 1934); Schmieg, Hungate \& Kotzian, Inc. v. Comm'r, 27 B. T. A. 337 (1932). However, there should be more than momentary control, 2 PaUl \& Mertens, op. cit. supra note 19, 206-207, without pre-existing commitments to sell the controlling stock. West Texas Refining \& Development Co. v. Comm'r, 25 B. T. A. 1254 (1932), aff'd, 68 F. (2d) 77 (C. C. A. 10th, 1933). Butt cf. Walter B. Lashar v. Comm'r, 34 B. T. A. 768 (1936); Evans Products Company v. Comm'r, 29 B. T. A. 992 (1934); Robert D. Green v. Comm'r, 24 B. T. A. 719 (1931).

22. The Liquidating Company v. Comm'r, 33 B. T. A. 1173, 1186 (1936); Ballwood Co. v. Comm'r, 30 B. T. A. 644, 649 (1934); McCord v. Comm'r, 31 B. 'T. A. 342 (1934).

23. See note 1 supra.

24. See Batr \& Morris, Hididen Taxes in Corporate Reorganizations (1935) 97-98.

25. Peck \& Peck v. Comm'r, 42 B. T. A. 651 (1940). See note 29 infra. 
If $P$, a parent corporation having eighty per cent or more stock control if its subsidiary $S$, transfers assets whose value is only a small percentage of $S$ 's net worth in return for stock of $S$, there appears to be a Part (D) reorganization. Though $P$ was in statutory control of $S$ before the property transfer, it is in control "immediately after," and the literal requisites of the definition are complied with. Pursuant to a plan of reorganization, $P$ has exchanged property for stock of another corporation, and, since both corporations are parties to the reorganization, no gain or loss is recognized. Furthermore, the basis provisions applicable to tax free exchanges offer an added opportunity for minimization of income tax by permitting strategic shifting of gains or losses between corporations. The statute provides that the tax basis to $S$ of property received from $P$ in a nontaxable exchange is the same as the basis of that property when it was in the hands of $P .20$ Suppose that $P$ is running at a small profit or a loss, while $S$ has large operating profits. If $P$ owns securities which have depreciated in value from their basis, it can transfer the securities to $S$ in a nontaxable exchange, $S$ taking $P$ 's basis for the securities. Later, $S$ sells the securities at a large loss and thereby reduces its income tax on operating profits. ${ }^{27}$ Such results are sanctioned by the case of Peck \& Pcck $v$. Commissioner. ${ }^{23}$ In this case $P$, with one hundred per cent control of $S$ both before and after the exchange, transferred a small part of its assets, stock in $S$, to $S$ in return for $P$ stock plus enough cash to make the exchange on the basis of fair market value for the stock of each corporation. The Board of Tax Appeals held that, except for the negligible amount of cash involved, the stock transfers constituted a Part (D) reorganization and a nontaxable exchange, $P$ continuing in control of $S$ "immediately after" the transfer. In so holding, the Board plainly took the position that there was no need for $P$ 's statutory control to arise out of the transfer. ${ }^{29}$

A slightly different problem in the interpretation of Part (D) occurs when two subsidiaries of a common parent exchange property for stock. Assume that $P_{1}$ has eighty per cent or more control of $S_{1}$ and $S_{2}$ and that

26. INT. REv. CoDE $\$ 113(a)(7)$ (1940); U. S. Treas. Reg. 103, $\$ 19.113(a)(7)-1$.

27. The loss would be a capital loss, either long or short term, deductible under the conditions prescribed by the statute for corporate capital losses. Ivт. Rv. Cove $\$ 117$ (1940) ; U. S. Treas. Reg. 103, § 19.117-1 \& 2.

28. 42 B. T. A. $651 .(1940)$, discussed at note 4 supra.

29. This is the only Part (D) case found which directly discusses the issue of whether or not control must arise out of an exchange. Without mentioning this point, some cases have held that there were reorganizations where statutory control arose out of a transfer. C. T. Inv. Co. v. Comm'r, 8S F. (2d) 582 (C. C. A. Sth, 1937); Ballwood Co. v. Comm'r, 30 B. T. A. 644 (1934); Rudolph Boehringer v. Comm'r, 29 B. T. A. 8 (1933) ; other courts, though their holdings on this point are capable of different interpretation, appear to have approved reorganizations where control did not arise ont of transfers. Comm'r v. Whitaker, $101 \mathrm{~F}$. (2d) 640 (C. C. A. 1st, 1938); Isidor Kahn v. Comm'r, 36 B. T. A. 954 (1937); H. B. Leary, Sr. v. Comm'r, 34 B. T. A. 1206 (1936), aff'd, 93 F. (2d) 826 (C. C. A. 4th, 1937). 
$S_{1}$ transfers property whose value is a small percentage of $S_{2}$ 's net worth in return for stock of $S_{2}$. "Immediately after" the transfer, $S_{1}$ and its shareholder $P_{1}$ together are in statutory control of $S_{2}$. The degree of control by $P_{1}$ over the property transferred to $S_{2}$ has changed, but it is not necessary that the shareholders of $S_{1}$ retain control of the severed assets proportional to their former stockholdings in the transferor. ${ }^{30}$ Since $P_{1}$ owned $S_{2}$ before the exchange, control of $S_{2}$ did not arise out of the transfer. Under the Peck case rationale, however, this is unnecessary to make the transaction a Part (D) reorganization and consequently nontaxable.

Essentially the same reorganization question raised in the preceding example is presented if the facts there stated are varied in this manner: $S_{\mathbf{2}}$ assumes a $\$ 5,000$ mortgage liability on the property transferred by $S_{1}$, and $S_{1}$ receives not $S_{2}$ stock alone but one hundred shares of such stock and $\$ 25,000$ in cash which is transferred to $S_{1}$ 's shareholders at once. "Immediately after" the exchange, $P_{1}$ and $S_{1}$ are in control of $S_{2}$. There is a Part (D) reorganization, and no gain or loss is recognized insofar as the one hundred shares of $S_{2}$ stock are concerned. By assuming the mortgage liability, $S_{2}$ in effect paid $S_{1} \$ 5,000$ additional compensation. This payment is not in stock, nor can it be immediately transferred to shareholders. The statute provides that no gain shall be recognized with respect to such pay* ments, ${ }^{31}$ and there can be no quarrel with this result because the basis for subsequent gain or loss on the $S_{2}$ stock received by $S_{1}$ is reduced in the amount of the mortgage liability assumed, $\$ 5,000 .{ }^{32}$ The vice of the plan is that by immediately distributing the $\$ 25,000$ in cash as a clividend, $S_{1}$ escapes tax liability for any gain with respect to the money received. ${ }^{83}$ Thus, a link in the chain of income taxation has been completely skipped. To permit complete tax exemption by this scheme is utter perversion of the reorganization provisions.

The rationale of the Peck case, with its emphasis not on the method by which control is acquired but on the status of control, logically covers situations where a transferor corporation, or its shareholders, or both, acquire eighty per cent domination of another corporation by a process known as creeping control..$^{34}$ If $P$ owns seventy per cent of the stock of $S$ and transfers property in return for an additional ten per cent of $S$ 's stock, it has acquired

30. Paul, Studies in Federal. Taxation-Third Series (1940) 75.

31. INr. REv. Code $\$ 112(k)$ (1940); U. S. Treas. Reg. 103, $\$ 19.112(k)-1$. For a general discussion of this question, see Surrey, Assumption of Indebtedness in Tax-Frec Exchanges (1940) 50 YALE L. J. 1, 15.

32. Int. Rev. Code $\$ 113$ (a) (6) (1940); U. S. Treas. Reg. 103, $\$ 19.113(a)(6)-2$. It is possible that this treatment could result in a minus basis on the $S_{2}$ stock to $S_{1}$. Such a basis would probably be treated as zero. Surrey, stipra note 31 , at 19.

33. If $S_{1}$ had retained all or part of the cash received, gain or loss on the exchange would have been taxable to the extent of the cash so retained. INT. REv. CoDE $\S 112$ (d) (2) (1940).

34. See BaAR \& Morris, op. cit. supra note 24 , at 75-76. 
eighty per cent creeping control of $S$. Likewise, if $S_{1}$ transfers property in return for ten per cent of the stock of $S_{2}, P_{1}$ having seventy per cent of the stock of $S_{1}$ and $S_{2}, S_{1}$ and its shareholder $P_{1}$ together have acquired eighty per cent creeping control of $S_{2}$. In neither case was there eighty per cent control of the transferee prior to the exchange, nor did statutory control arise out of the final ten per cent stock acquisition itself, but eighty per cent control did exist after the exchange. Hence, there is a Part (D) reorganization and a nontaxable exchange.

Similar to the problems of interpreting Part (D) are the questions raised by the reorganization definition in Part (B). ${ }^{35}$ A reorganization is there defined as "the acquisition by one corporation, in exchange solely for all or a part of its voting stock, of at least eighty per centum of the voting stock and at least eighty per centum of the total number of shares of all other classes of stock of another corporation." Amendments since 1932 have accentuated the distinctions which formerly existed between Parts (D) and (B), ${ }^{36}$ and each is now directed to a different factual situation. Part (D) addresses itself to situations where property is transferred to a corporation and, "immediately after," the transferor corporation or its shareholders control the transferee. Part (B) is concerned with a situation where, in exchange solely for its voting stock, one corporation acquires stock control of another corporation from that corporation or its shareholders. Thus, a judicial rule of construction under Part (D) is not necessarily binding for Part (B). Upon literal interpretation, the "immediately after" in Part (D) does seem to mean control status only. But the key word in Part (B), "acquisition," has been said to imply the process of obtaining eighty per cent control within the limits of a single plan, rather than a control status existing after an exchange has occurred. ${ }^{37}$

35. INT. Rev. CODE §112(g) (1) (B) (1940).

36. The predecessor of Part (B) was the stock acquisition part of the old "parenthetical clause" which appeared in $\$ 112(\mathrm{i})(1)(\mathrm{A})$ of the Revenue Acts of 1932 and $1928, \S 203(\mathrm{~h})(1)(\mathrm{A})$ of the Revenue Acts of 1926 and 1924, $\S 202(\mathrm{c})(2)$ [2] of the Revenue Act of 1921. The "parenthetical clause" required only majority control to constitute a reorganization, and it permitted transfers of property as well as the issuance of stock to a corporation in exchange for stock. Thus corporations wishing to by-pass the $80 \%$ control rule of Part (D)'s predecessors could transfer property in exchange for majority control of another corporation and get a tax-free reorganization under the "parenthetical clause." Rawco, Inc. Ltd. v. Comm'r, 37 B. T. A. 128, 139 (1938) ; sge United Light \& Power Co. v. Comm'r, 38 B. T. A. 477, 486 (1938), aff'd, 105 F. (2d) 865,877 (C. C. A. 7th, 1939), cert. denied, 30 S U. S. 574 (1939) (both eases decided under $\$ 112(\mathrm{i})(1)(\mathrm{A})$ of the Revenue Act of 1928). Such a maneuver has become impossible since $\$ 112(\mathrm{~g})(1)(B)$ of the Revenue Act of $193+$ became effective, for it and subsequent Acts have demanded that there be eighty per cent control and that the controlling corporation issue only its voting stock, not property.

37. 2 PaUl \& MIertens, op. cit. supra note 19, \$17.78. Contra: Paur, op. cit. susro

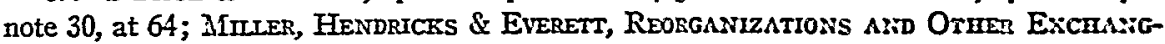
es in Federal Income Taxation (1931) 114. See BaAr \& Mforprs, op. cil. sisfra note 24 , at 75 . 
Under Part (B) then, if $P$ is in statutory control of $S$ both before and after an exchange of stock with relatively small value, or if $P$ owns seventy per cent of $S$ 's stock and has eighty per cent creeping control of $S$ after an exchange, it might appear that there was no reorganization because statutory control did not arise out of the exchange. But, as in Part (D), the courts have confined their attention to the control status after a plan has been completed. If the eighty per cent requirement is satisfied, there is a Part (B) reorganization and a nontaxable exchange. ${ }^{38}$ This result also permits the strategic shifting of gain or loss between taxpayers. Suppose that a stockholder of $S$ has a block of $S$ stock at a basis much higher than its present market value. $P$ has a large operating profit and is anxious to reduce the tax on it, so $P$ transfers some of its voting stock to $S$ 's stockholder in return for his stock in $S$. If $P$ has eighty per cent control of $S$ after the exchange, there is a reorganization, and the basis of the $S$ stock to $P$ is the same high figure which the stockholder had. ${ }^{30}$ Later, $P$ sells the $S$ stock at current values and sustains a large loss, thereby reducing its income tax on operating profits. ${ }^{40}$

The exchanges in the various situations discussed under Parts (D) and (B) .involve relatively small amounts of property and stock, and have all the earmarks of taxable sales or exchanges. In the examples where eighty per cent control of a subsidiary existed before and after an exchange, values were stated to be small in relation to the net worth of the subsidiary. In the creeping control examples values were limited to ten per cent of the subsidiary's net worth. That the consideration received by the transferor was stock rather than cash in all cases except one of the common control examples should not bar the recognition of gain or loss on these transfers. Among the corporations in a parent-subsidiary relationship, cash may be easily shunted from one to the other, and stock can be and often is appraised at its fair market value and treated as cash. Since the value of the stock or property transferred is relatively small, taxation of a resultant gain would not be more than a corporation's treasury could bear. Nontaxability appears

38. Comm'r v. Dana, 36 B. T. A. 97, 104 (1937), aff'd, 103 F. (2d) 359, 361 (C. C. A. 3d, 1939), cited supra note 4. The court clearly held that control need not arisc out of the exchange. Rawco, Inc., Ltd. v. Comm'r, 37 B. T. A. 128 (1938) semlle. Statutory control did arise out of this exchange, but the language of the opinion indicates that prior stockholdings of the acquiring corporation were included in the total number of sharcs which the Board considered in determining that there was statutory controp.

In almost all cases examined where there were successful reorganizations, statutory control did arise out of the transaction, but the method by which control should be acquired was not in issue and was not discussed in the opinion. For examples, Watts $v$. Comm'r, 75 F. (2d) 981 (C. C. A. 2d, 1935); Daisy M. Ward v. Comm'r, 29 B. T. A. 1251 (1934); William John McCabe v. Comm'r, 29 B. T. A. 1096 (1934); Edison Sccurities Corp. v. Comm'r, 29 B. T. A. 483, 493 (1933), rev'd and remanded on other grounds, 78 F. (2d) 85 (C. C. A. 4th, 1935).

39. INT. Rev. Code $\S 113$ (a) (7) (1940) ; U. S. Treas. Reg. 103, §19.113(a) (7)-1.

40. See note 27 supra. 
clearly contrary to the underlying policy of the nonrecognition provisions that taxation of mere paper profits should be deferred only where it would seriously impede normal business adjustments. MIoreover, Congress adopted a general policy against tax freedom in transactions between affiliated companies when it abolished consolidated income tax returns in the Revenue Act of 1934.41 Unless an exchange comes clearly within the letter and spirit of the reorganization and nonrecognition provisions, this policy should prevail. ${ }^{42}$

These considerations call for the taxation of gain or loss on exchanges of property or stock with values which are small in relation to the net worth of the controlled corporation. But, when the value of the property or stock exchanged is relatively large, they admit nontaxability on the theory of facilitating bona-fide alterations in corporate structure. Under the present eighty per cent requirement the Commissioner's contention that control must arise out of the exchange would limit tax freedom to plans of reorganization which convey at least eighty per cent control. On policy grounds this is an unsatisfactory result. If a corporation in eighty per cent control of a subsidiary receives stock in exchange for property or voting stock of three times the value of the subsidiary's net worth, or if a corporation with ten per cent control of another acquires eighty per cent creeping control of the latter by an exchange of property or voting stock, there probably should be Part (D) or Part (B) reorganizations and nontaxability, but statutory control does not arise out of the transaction. Thus, while the doctrine for which the Commissioner contended prevents unwarranted tax avoidance in exchanges of small value, it does not protect taxpayers against taxation in some situations where there are exchanges of relatively large value.

A modification of the Commissioner's contention is proposed. The extent of the control which actually arises out of an exchange is not mentioned in the Code. There is no need that it be the same as the eighty per cent control necessary for a reorganization. It is a subject for judicial construction. The wording of Part (D) provides no obstacle to the proposed solution, and the

41. Morris, Tax Currents as Reflected by the Reacuue Ad of 1934. XII TAx Mag. 585, 586 (1934); Mralina, The Revente Act of 1934, XII Tax Mrag. 406, 408 (1934).

The elimination of gain or loss upon intercompany transactions between affiliated companies filing consolidated returns was a tax deferring device. PEance, Ircose Tax Fundantentals (1937) 321, 324; see also 4 Paur \& Mientens, The Law of Fereral I:CONE TAXATION (1934) $\$ \$ 38.02,38.07,38.13$. Consolidated returns for affiliated corporations were authorized by the tax statute from 1918-1934. Tyler and Ohl, The Revente Adt of 1934 (1935) 83 U. oF PA. L. KEv. 607, 617. The Revenue Act of 1934 permitted only railroad corporations to file consolidated returns, 402 C. C. H. 1940 Fed. Tax Serv. p. 3313, and this was for a special reason. Selnasis, of. cit. supro note 5, at 378 . This exception still exists. INT. REv. CODE $\$ 141$ (1940). A similar exception has existed since 1939 for the benefit of Pan-American trade corporations. INT. REv. Covz $\$ 152$ (1940).

42. See Case v. Comm'r, 37 B. T. A. 365, 370 (1938); Charles Hall v. Comm'r, 31 B. T. A. 125,129 (1934). 
word "acquisition" in Part (B) need not be interpreted as requiring statutory control to be obtained in one transaction. With the proposed concept the courts could distinguish their treatment of situations in which the control arises out of exchanges of relatively large or relatively small values, allowing a reorganization and nontaxability where the values are large but denying one when the values are small. This treatment would achieve the policy aims of the reorganization and nonrecognition provisions in all the situations considered, especially by denying success to the flagrant schemes for shifting gain or loss among taxpayers. The evolution of such a doctrine would require considerably less judicial imagination than the courts have displayed in developing other doctrines to defeat tax avoidance by way of reorganization..$^{43}$ Ordinarily, the line of distinction between large and small values can best be drawn with relation to the net worth of the controlled corporation. Perhaps the top limit for relatively small values should be somewhere between twenty and forty per cent of the net worth of the controlled corporation; conversely, the bottom limit for relatively large values, nontaxable, would be between sixty and eighty per cent.

Utilization of the proposed control doctrine in the manner suggested may result in the recognition of gain or loss where there has been a capital investment with no intent to make an ordinary taxable sale or exchange or to shift gain or loss. If one corporation desires to transfer a small amount of property to an affiliated corporation as additional capital, or if a corporation, for legitimate purposes of control, wishes to acquire a small amount of stock in another corporation by issuing its voting stock, the proposed doctrine will cause the recognition of gain or loss on these exchanges if the transferor corporation or its shareholders [Part (D)] or the acquiring corporation [Part (B) ] is in eighty per cent control after the exchange. But if the additional capital investment is bona-fide, the value and basis of the property transferred or the voting stock issued will usually approximate value of the stock received therefor. Hence there will be little or no gain or loss on the exchange. On the other hand, if the value of property transferred is in excess of the basis of such property to the transferor, gain should be recognized and taxed. The reorganization and nonrecognition provisions are not aimed at protecting from taxation gain or loss on small capital investments which take the form of property or stock exchanges. If the investment is cash for stock of the transferee, no question of gain or loss can occur.

The Supreme Court has not yet spoken on this control problem, but lower courts have refused to consider questions of policy and have uniformly held that an eighty per cent control status at the conclusion of an exchange warrants the reorganization label with its consequent nontaxability. ${ }^{44}$ No cases have been discovered which decide two of the issues raised in the examples pre-

43. Notably, the "continuity of interest" doctrine, p. 1251 infra, and the "business purpose" doctrine, p. 1247 infra.

44. See pp. 1241, 1244 supra. 
sented: First, where a corporation, in statutory control of another before and after an exchange, enters into a plan of reorganization intending to shift gain or loss in order to minimize taxation, a consideration of control status alone warrants a reorganization and success to the scheme. But, even without the proposed control doctrine, the scheme might be attacked on the ground that it was simply a tax-dodging device and served no business purpose. Under these circumstances, however, it would be difficult to invoke the business purpose doctrine of Gregory $v$. Hclvcring. ${ }^{\text {t5 }}$ A bona-fide business transfer is perfectly legal even though one of its known and intended results will be tax avoidance. ${ }^{46}$ Proof of complete lack of business purpose would probably present considerable difficulties. Second, where two subsidiaries under the common control of a parent exchange property for stock or for stock and cash, there would be a Part (D) reorganization under the rationale of the Peck case. But this case is readily distinguishable on its facts. It involved only a direct parent-subsidiary property transfer, not an exchange between common subsidiaries of one parent. Moreover, the words of Part (D) which create a reorganization if the transferor or its shareholders or both are in control of the transferee seem to indicate a Congressional intent that shareholder control shall exist only by reason of such shareholders' being shareholders in the transferor. In none of the common control examples was this criterion satisfied. Thus, under existing law and without the proposed control doctrine, there need be no reorganization in the common control situation, and policy considerations demand that there should be none. Particularly is this true where the transferor subsidiary receives its consideration principally in cash which is immediately distributed to its shareholders. Part (D) should not be unnecessarily utilized to shield from taxation the gain upon an exchange which is so clearly a sale for cash.

\section{II.}

\section{Property Transfers to a Corporation Under Section 112(b)(5)}

Section 112(b) (5) of the Internal Revenue Code raises legal issues which are almost identical with those raised by the Part (D) reorganization examples where a transferor corporation is in eighty per cent control of a transferee corporation before and after an exchange or where there is an exchange in which a transferor corporation acquires eighty per cent creeping control of its transferee. It is, however, directed toward a factual situation different from that to which Part (D) is applicable. The Section provides that "no gain or loss shall be recognized if property is transferred to a corporation

45. 293 U. S. 465 (1935). Sandberg, Inconte Tax Srbsidy to "Reorganizalions" (1938) 38 CoL. L. REv. 98, 110 et seq.

46. Ibid.; Eaton v. White, 70 F. (2d) 449, 451 (C. C. A. 1st, 1934). See United States v. Isham, 17 Wall. 496,506 (U. S. 1873). 
by one or more persons solely in exchange for stock or securities in such corporation, and immediately after . . . such person or persons are in control of the corporation. . . ." The word "person" includes but is not limited to a corporation; $4 \pi$ it clearly does not include a corporation's shareholders. Part (D) applies only to transfers from one corporation to another, but the transferor corporation or its shareholders or both may be in control of the transferee. Section 112(b)(5), then, is not applicable to situations like the Part (D) examples where there is an exchange between stbsidiaries of a common parent. It is primarily designed for transfers where a sole proprietor, a partnership, or two or more individuals are incorporating their assets, or where two or more corporations are consolidating. Part (D) is drafted for the splitting up of a corporation. When, in a property transfer to a corporation, the consideration received by the transferor(s) is stock and cash, gain or loss on the exchange is recognized to the extent of the cash received.88 If the transferor is a corporation, taxation may not be escaped on gains to the extent of the cash received, as is possible in a Part (D) exchange, by immediately transferring the cash to the corporate shareholders. ${ }^{40}$

Where two or more persons transfer property to a corporation, the application of Section 112(b) (5) is restricted to instances where the stock which each transferor receives is substantially in proportion to his interest in the property prior to the exchange. If $A$ and $B$, with eighty per cent or more stock control of $C$ corporation, transfer to $C$ property whose value is a small percentage of $C$ 's net worth in return for shares of stock which are substantially proportional to the value of the property transferred by each, $A$ and $B$ are in statutory control "immediately after" the exchange, and there appears to be nonrecognition of gain or loss under Section 112(b) (5). The same result would attend if $A$ and $B$, with seventy per cent of $C$ 's stock, transfer property to $C$ in return for shares of stock which are proportional to the value of the property which each transferred so that $A$ and $B$ have eighty per cent creeping control of $C$. If the property transferred by either $A$ or $B$ were subject to a liability, or if $C$ assumed a liability of either $A$ or $B$, the amount of the liability would be considered as stock for purposes of determining whether the transferor involved received stock in proportion to his interest to the property transferred.50 Statutory control does not arisc out of these exchanges, but it does exist afterward. No case has been found which discusses the question of how control should be acquired under Section

47. INT. REv. CoDE §3797(a) (1) (1940).

48. INT. REv. CODE §112(c) (1) (1940).

49. INT. Rev. CODE $\S 112$ (d) (1) (1940) is not applicable to $\S 112$ (b) (5) exchanges; it is pertinent only to $\S 112(\mathrm{~b})(4)$ transfers.

50. INT. Rev. Code $\$ 112(\mathrm{~b})(5)$ (1940). See Surrey, Assumption of Indebtedness in Tax-Free Exchanges (1940) 50 YaLE L. J. 1, 25. 
112(b) (5), ${ }^{51}$ but the issue is apparently the same as in Part (D) reurganizations. It seems irrelevant that the transferor in Part (D) must be a corporation, while in Section 112(b)(5) any person or persons may be transferors. The crucial words "immediately after" appear in buth places in connection with nonrecognition of gain or loss in property transfers to a corporation. Congress presumably intended them to have the same meaning in both places. The Peck case, which arose on an interpretation of Part (D), held that control need not arise out of the transfer. Thus, it seems logical that there be nonrecognition of gain or loss under Section 112(b) (5) if statutory control does not arise out of but merely exists after an exchange.

Suppose that three stockholders with ninety-two per cent stock control of W. \& K. Holding Corporation individually own securities which have greatly depreciated in value from their tax bases. W. \& $K$. has a large profit, and the three stockholders, anxious to reduce W. \& K.'s income tax, transfer their depreciated securities in return for stock in W. \& K. Since a statutory control status exists after the transfer, Section $112(b)(5)$ may be said to apply. There being nonrecognition of gain or loss on the exchange, the basis of the depreciated securities is the same to W. \& K. as it was to the transferor stockholders. Later in the year, W. \& K. sells the securities and takes a large capital loss, thereby reducing its income tax. On the facts stated, this result has been sanctioned by the Board of Tax Appeals in the $W . \& K$. Holding Corporation case. ${ }^{52}$ Though the scheme was purely and simply a tax-dodging device without business purpose, the Board refused to prevent its success by invoking the business purpose doctrine of Gregory 2 . Helvering on the ground that the Gregory case applied only to reorganizations, not to nontaxable exchanges under Section 112(b)(5).

The factual situations presented under Section 112(b) (5) involved property exchanges of small value relative to the net worth of the transferee corporations which have all the characteristics of taxable sales and exchanges. Taxation of gains on such exchanges would not be more than the transferor should bear. Nontaxability appears clearly contrary to the underlying policy of the nonrecognition provisions that taxation of mere paper profits should be deferred only where it would seriously interfere with normal business adjustments. Conversely, if the value of the property exchanged is relatively

51. Courts have allowed nonrecognition of gain or loss sub silcutio where control arose out of the exchange. Snead v. Jackson Securities and Investment Co., 77 F. (2d) 19 (C. C. A. 5th, 1935) ; R. C. Kuldell v. Comm'r, 34 B. T. A. 1116 (1936); Amerian Compress \& Warehouse Co. v. Bender, 70 F. (2d) 655 (C. C. A. Sth, 1934); Sehmieg, Hungate \& Kotzian, Inc. v. Comm'r, 27 B. T. A. 337 (1932) ; Carel Robinson v. Comm'r, 19 B. T. A. 751 (1930) ; Labrot v. Burnet, 57 F. (2d) 413 (App. D. C. 1932); see examples in Reg's. 103, §19.112(b)(5)-1. Still sub silentio, they have also permitted tax freedom in exchanges where control did not arise out of the transfer. W. \& $K$. Holding Corporation v. Comm'r, 38 B. T. A. 830 (1938); Bilicke v. Comm'r, 20 B. T. A. 784 (1930) semble.

52. 38 B. T. A. 830 (1938). 
large, there should be nontaxability. Should the control doctrine proposed in the discussion of Parts (D) and (B) of the reorganization definition be applied here, it would permit the courts to tax gains in exchanges of relatively small values and to give tax freedom where relatively large values are involved on the rationale of the degree of control arising out of the exchange. If property of relatively small value is transferred to a corporation in exchange for stock as an additional capital investment by persons in eighty per cent control of the transferee, gain or loss on the exchange will be recognized. But this is not an objection to the proposed doctrine. There is no policy reason within Section 112 (b) (5) which requires nontaxability when there is a capital investment instead of the ordinary sale or exchange. Application of the control doctrine would prevent the inequitable tax consequences stemming from the Peck and $W . \mathcal{E} K$. Holding Corporation cases. Under the statute and these decisions, controlling shareholders of a corporation who have property to dispose of can sell it to the corporation for cash and sustain taxable gain or loss, or they can sell the property for stock, permitting the corporation to take the gain or loss on a subsequent sale.

\section{III.}

\section{Exchanges of Small Value Between Unaffiliated Corporations as Part (D) Reorgantzations}

Should the courts continue to look only to control status at the conclusion of a transaction, tax freedom under the Part (D) reorganization definition may yet extend to exchanges of property for stock which are nothing but subterfuges to escape taxation on what are clearly sales. Suppose that $S$, under eighty per cent or more control of $P$ corporation, must buy property of small value relative to its net worth from $X$, an unaffiliated corporation. If the market value of the property substantially exceeds its basis to $X, X$ may be anxious to avoid a sale because it will thereby realize a large taxable gain. Accordingly, a deal is worked out whereby $P$ purchases a few shares of $X$ stock. $X$ then transfers the property to $S$ in return for stock in $S$. The trick is done! "Immediately after" the consummation of the plan, $X$ and its stockholder $P$ together are in statutory control of $S$. There is a Part (D) reorganization and a nontaxable exchange. The basis to $X$ of the stock in $S$ is the same as the basis of the property transferred. At some future date when $X$ has a taxable loss which may be offset against a gain, $X$ can sell its stock in $S$ and realize taxable gain without suffering the pains of taxation.

It is improbable that this scheme could be defeated by invocation of the business purpose doctrine of Gregory $v$. Helvering because the tax avoidance aspects of the exchange were subordinate to $S$ 's acquisition of X's property, a legitimate business purpose. ${ }^{53}$ But application of the proposed control

53. See p. 1247 sipra. 
doctrine would result in recognition of gain or loss on such a transfer because the extent of the control in $S$ arising out of the exchange is insufficient to warrant a Part (D) reorganization.

On the basis of existing law and without the proposed concept, gain on the exchange might be taxed under a recently developed variation on the established continuity of interest doctrine. The established continuity of interest doctrine requires that the transferor or its stockholders retain a definite and substantial interest in the value of the assets which it conveys to another corporation, ${ }^{64}$ but all stockholders of the transferor need not retain an interest in the severed assets. ${ }^{65}$ It has had its principal application not in connection with Part (D) but in situations where a transferor corporation conveys substantially all of its assets to another corporation. Nevertheless, the doctrine was evolved to prevent tax avoidance, ${ }^{\mathrm{br}}$ and reasonable variations on it should be equally applicable to Part (D) reorganizations. In Weicker v. Howbert, ${ }^{\text {b8 }} L$ corporation transferred part of its assets to $M$ corporation in return for all of $M Y^{\prime}$ s stock, which was then distributed to some of $L$ 's stockholders in exchange for stock in $L$. Majority stock control of $M$ ultimately went to a former substantial shareholder in $L$ who, because of exchanging stock in $L$ for $M$ stock, now held either one or no shares of $L$ stock. Assuming that control of $D I$ rested in $L$ 's stocliholder with one share, there appeared to be a Part (D) reorganization, for "immediately after" the transfer one of $L$ 's shareholders was in control of $M$. But the court held that $M$ 's controlling shareholder did not retain a sufficient interest in $L$ for the control of $M I$ to be in a shareholder of $L$ who had a real and continuing interest in the policies and affairs of $L$; there was not the requisite continuity of interest. ${ }^{60}$ Applying this doctrine to the fore-

54. Helvering v. Minnesota Tea Co., 296 U. S. 378 (1935); Cortland Specialty Co. v. Comm'r, 60 F. (2d) 937 (C. C. A. 2d, 1937), cert. denied, 288 U. S. 599 (1933). See generally Comment (1940) 49 YALE L. J. 1079.

55. Weicker v. Howbert, 103 F. (2d) 105, 109 (C. C. A. 10th, 1939).

56. These situations arose formerly under the property acquisition part of the "parenthetical clause" of earlier Revenue Acts. (See note 36 stpra). The present counterpart of the old provision, INT. REv. CODE $\$ 112(\mathrm{~g})(1)(C)(1940)$, no longer presents a continuity of interest problem, for continuity of interest requirements have been legislated into the Code's new definition. Comment (1940) 49 Y ALE L. J. 1079, 1089.

57. BaAr \& Morris, Hrdden Taxes in Corporate Reorganizations (1935) 52-55; Comment (1940) 49 YaLE L. J. 1079, 1080. See also note 54 supro.

58. 103 F. (2d) 105 (C. C. A. 10th, 1939).

59. In the past few years, courts have said that there must be continuity of interest in all tax reorganizations. Hendee v. Comm'r, 98 F. (2d) 934, 936 (C. C. A.7th, 1938); Sam Pickard v. Comm'r, 40 B. T. A. 258 (1939). In two cases involving predecessor provisions of Part (D), judges placed considerable emplassis on the lack of continuity of interest in refusing to recognize a reorganization, though the actual holding was probably based on another ground. Case v. Comm'r, 37 B. T. A. 365, 370, 372 (1938), aff'd on reorganization issue but reversed on other grounds, 103 F. (2d) 283 (C. C. A. 9th, 1939); Robert M. Morgan v. Comm'r, 41 B. T. A. 379, 387 (1940). The continuity of interest must be directly between transferor and transferee; it may not be by way of 
going example of a property exchange between $S$ and $X$, it is apparent that $P$, the controller of $S$, does not have that substantial and continuing interest in $X$ which would warrant a reorganization and a nontaxable exchange.

IV.

\section{Concrusion}

Nonrecognition of gain or loss under the reorganization and exchange provisions of the federal income tax is an exception to the general rule of the tax statute that gain or loss be recognized upon a sale or exchange. Exceptions are to be strictly construed, nonrecognition being accorded only if the exchange satisfies the literal wording and the underlying purpose of the exception. That the consideration received on an exchange is stock rather than cash should not bring the transaction within the nonrecognition exception, for stock is often appraised at its fair market value and treated as cash. The Congressional purpose of the reorganization and exchange provisions is to avoid serious interference with normal corporate mergers and consolidations by refraining from the taxation of the paper profits which may result from these business adjustments. Since a tax on gains from exchanges involving small values relative to the net worth of a controlled corporation would not be great enough to interfere seriously with normal business adjustments, a line of distinction should be drawn betwcen relatively small and relatively large values. The Commissioner's contention that eighty per cent control must arise out of the exchange itself prevents unwarranted tax avoidance in transfers of small value, but it does not afford freedom from taxation in some situations where there are exchanges of large value. The proposed doctrine that the courts interpret the control which actually ariscs out of an exchange to tax gains on exchanges of small value but to confer nonrecognition of gain or loss on exchanges of large value is an adaptation of the Commissioner's contention which satisfies the wording and policy of the Code.

In their decisions the courts state that statutory control at the conclusion of an exchange warrants nontaxability, regardless of whether the values involved are relatively large or small. Hence, there are reorganizations and tax freedom under Parts (D) and (B) of the definition and nontaxable property transfers under Section 112(b) (5) if there are transfers of property or exchanges of stock where one corporation is under statutory control before and after the transaction or where creeping control grows out of the transfer. Even though such exchanges are entered into for the purpose of shifting gain or loss between taxpayers, the business purpose doctrine is probably

stock holdings in the parent of a transferee. United Light \& Power Co. v. Comm'r, 38 B. T. A. 477,486 (1938), aff'd, 105 F. (2d) 866, 877 (C. C. A. 7th, 1939), cert. denicd, 308 U. S. 574 (1939). 
inadequate to prevent tax avoidance. The decided cases do not cover factual situations in which property is exchanged between two subsidiaries under the control of a common parent. Where a subsidiary under eighty per cent control of its parent transfers its stock in payment for property of a corporation in which the parent owns but few shares, a variation on the continuity of interest doctrine could be used to prevent tax avoidance. But here, as in the common control situation, the control status rationale adopted by the courts might be extended to permit nonrecognition of gain or loss. The proposed control doctrine would enable the courts to plug all of these tax avoidance loopholes by distinguishing between exchanges of relatively small and relatively large values. 